\title{
Development of Presentation Model with Cloud Based Infrastructure
}

\author{
Maria Magdalena Widiantari ${ }^{1}$, and Arief Budiman ${ }^{2, *}$ \\ ${ }^{1}$ Program Study of Communication Sciences, Merdeka University of Madiun, Jl. Serayu No. 79, \\ Madiun, East Java, 63133, Indonesia \\ ${ }^{2}$ Program Study of Informatics Management, Merdeka University of Madiun, Jl. Serayu No. 79, \\ Madiun, East Java, 63133, Indonesia
}

\begin{abstract}
Computer mediated communication are the communication activities using technology which have rapidly in progress. Communication interactive activities nowadays has no longer only involving person to person but mediated by technology, and have been done in many fields including in education and teaching activity. In this study, presentation media based on cloud's infrastructure designed to replace face to face or in class lectures. In addition, the presentation will allow media data storage indefinitely, and accessible wherever and anytime. This is in line with the concept of student center learning where students were encouraged to more active in the lecture activities. The purpose of this research is making or designing a presentation model based on cloud's infrastructure. This research is using research and development method which is consists of four stages, where the first phase is composing the concept of media presentation design. The second phase are choosing the subject that will be designed as the subject of presentation. The third stage is designing presentation model. And the fourth phase is collecting materials of the subject that will be presented by each lecturer.
\end{abstract}

Key words: Cloud, internet, lecture, presentation, student center learning.

\section{Background}

In 2011 was the new era beginning of cloud computing technology, where there was some many providers which quite popular like dropbox, google drive, icloud dan skydrive [1]. Along with the quick progress of internet technology development, online digital storage

* Corresponding author: arief@unmer-madiun.ac.id 
media known as cloud's getting more popular. The Indonesian people served well with cloud service where they could have access their data anywhere and anytime, so users could increase and decrease the use of service and the computing resources both easily and flexible. Users do not need to made a large investment for computing resources, storage media, the cost of management system maintenance, network and database [2].

It is also felt by company or agency that running their business core no longer based on a local server or long distance server. Company or agency were also have the ability to provides central data services like company internet access, so they could provide their own storage data services to meet their needs $[3,4]$. On the other side, especially in the urban life, cause the changing of life behavior where pushing the community to use the cloud service to share and collaborated [6].

As the advancement of information technology and communication, media communication between faculty and students also progressively. Besides face-to-face communication, faculty and students also could interact through email, mailing list, social media, or short message service. Easy access to the internet made the communication between faculty and students can be done by internet media. So it was necessary to developed a presentation model that can be accessed wherever and anytime with the service of clud storage, that would give ease in the process of presentation material dissemination without having dependency of a limited storage medium and must always be brought and, and can be accessed anytime and wherever. This presentation model were also could replace the face-to-face lecture if there is a missed meeting that could happen at any time.

\section{Literature review}

\subsection{Computer mediated communication}

In line with the developments in communication and information technology, the context of communication between humans also developed. Consider the history of mass media, also have technology development, now with the development of digital technology especially computer, the context of communication was increasing. Now, communication activities between humans has grown in the context of computer mediated communication. The practice of computer mediated communication has been actually done in our daily life. The simplest was short message service, sending e-mail, chat through instant message or chat on facebook or tweeter, or other various forms social media.

One of the unique things going on in the computer based media communication was based on the power of text or words and non verbal symbols like emoticons, pictures and graphic. Because it was based on the strength of the text, the message displayed itself should be prepared or designed in such a way. Therefore, written communication or textual was not same with the technique of oral communication like face to face communication. However, the response delivered could be as an delayed feedback so that any response could be prepared in a more carefull.

Today the learning process in lecture, not only introduced a classic learning technique where the students seen as the object of education. Now the education forced the students to active in various kinds of other learning activities and be the subject of education itself. Effective learning will set the students on the activity that able to attract all of the optimal potention. In Nasution [6] research shown that there was a view activities of sthe students, it is:

i). Visual activities, like reading, seeing pictures, and demonstration or practice.

ii). Oral activities, like speech, to formulate, asking, giving advice, issued opinion, doing interview, discussion and interruption. 
iii). Listening activities, like Listening to discussion, conversation, discussion, music and speech.

iv). Writting activities, like writing a story, a wreath, creating test report, quisionare and copying.

v). Drawing activities, like painting, create a graphics, creating map, diagram and pattern.

vi). Motor activities, like doing experiments, constructions, modeling, reparation, playing, gardening, and look after pets.

vii). Mental activities, like remembering, solving a question, analyze, seeing relationship and make decisions.

viii). Emotional activities, like put on interest, feeling bored, happy, quiet and nervous.

In the lecture activities involving communication between faculty and students, development in information technology and communication also support the activities. Easy access to the internet made the communication between faculty and students could be done in the internet media, both in the personal communications or related to lecture activities. So, every lecturers and students are required to know how to work with internet based communication media, so that it could be used more effective.

The development of information technologies and communication change the way of human life including ways to communicate. Now human lived in age where the various form of information and various accuracy levels easily obtained. In education world, so many learning material, college material, and literatures that can be easily get. Information and communication technology also allows faculty and students to sent and exchange messages each other related with lecture material and assignment easily, cheap and fast. The learning process in lecture could modified in such a way that the lecture material could be diseminated through information and communication technology, while the lecture faceto-face meeting can be used to facilitate and push the student to understand certain college material.

It is possible, because the easy access to information through the internet, students could find information or lecture material first than lecturers. In this case, lecturers become the facilitator to push students understanding to the lecture material. Or in a face-to-face meeting, the items shared through the internet could be as a discussion material so that it can be extending the perspectives and strengthen students understanding.

\subsection{Multimedia based learning}

In the learning and lecture process, there were many strategy that could be chosen by lectures, like talk, discussion class, working group or other learning activities. In all strategy selected, effective communication should be important factor to support the purpose of learning activities. Learning strategy through speech was a classic way of lecture activities. Seen from time perspective, this model considered efficient, to convey many information gived to students with the minimal used of media, but this learning method less effective because students act passively, just hear, noted, and less encourage activities higher learning stage like analysis, synthesis or evaluation.

Another learning model that usually used by lecturer to create active learning condition was discussion team or workgroup. In this model lecturer act as a manajer that controlling the discussion team or workgroup doing their duties, to make sure that it would be working interactively in communication and provide information needed by each group. In the lecture activities based on a learning source, lecturers can serve as coordinator and an innovator. Learning communication not only relate to the lecturer verbal communication skill, but also the ability of designing a source of learning and learning media. Other media which could be learning tools like movie, video, magazine, the internet and many of 
presentation media that served in multimedia based. The present of media and the learning source would facilitate lecturers in communicate the learning. So a lecturers had to master and understand the learning source and learning media effectively so the utilization would increase the quality of learning.

Multimedia based learning being one learning model that is essential to developed along with the technology development. According to Arsyad [7] in his research said that multimedia traditionally refer to the use of several media, while multimedia in nowdays refer to the use of joint several media in learning presentation through the computer. Multimedia as presentation media different from the multimedia as a learning media. Presentation media did not demand the user to have active even though there is interactivity inside the activity then it called vogue interactivity. In this case, between lecturer and student could have face-to-face meetings where lecturers use multimedia-based presentations and deepened through lectures. Or students could access presentation media without face-to-face meetings, and on the other the opportunity on face to face discussion can be done to deepen the understanding of lecture material.

While multimedia as a learning media involve users in activities that demand mental processes in learning activity. Based on this perspective, specific mental activity required in learning could be raised through the manipulation of systematic instructional events. Based on it multimedia learning was package of interactive multimedia where there was instructional steps designed to involve users actively in learning. There are several forms of multimedia based learning. According to Arsyad [7] there were four forms of multimedia learning that usually used to described ways of learning using information technology, it was:

i). Programed model tutorial, set of views whether static or dynamic that already set before.

ii). Intelligent model tutorial, different form programmed tutorial because the answer from the computer were generate artificially.

iii). Drill modelled practice, it was a model to strengthen the mastery of concept.

Simulation Model, Simulation on a computer provides an opportunity to learn in dynamic, interactive and individual, just like in the real activity.

\subsection{Cloud based applications}

Cloud computing was new concept in information technology implementation, where cloud computing used to provide storage and application that could accessed from computer network with central data [8]. And some big companies had develop and implemented like Amazon, Microsoft, and Google [9]. There were three models of cloud computing services, it was Infrastructure as a Service (IaaS), Platform as a Service (PaaS), and Software as a Service (SaaS) [10]. Where on those three models, users did not participate to manage and check the network infrastructure, server, operating system, storage media and application used.

There were four model implementation of cloud computing it were private cloud, community cloud, public cloud, and the hybrid cloud. When cloud infrastructure owned by an organization and limiting the user access to the application using firewall it called as a personal cloud. However when an organization provide cloud services to a community with common organization purpose and to support the achievement of organization main objective it is called as a community cloud. The cloud services provided to users in general purpose without explicit goals and managed by an organization that aims to give a good cloud service at no charge it was called as a public cloud, whereas for the combination of several service called as a hybrid cloud. 
There were five major challenges and it needs special attention in the implementation of the cloud computing, it were security, interoperability, availability, performance, data and migration. Security focus on the privacy of data stored on the clouds services, secrecy, and network access. Interopability provide easy services, and offered some choice option needed by the user. The availability and performance guarantee the service were always ready to used by users. And the last was a problem in data and ability to perform data migration between cloud services, until now this would be the greatest challenges that had to be solved [8].

Multimedia based learning could be packaged to be multimedia learning presentation media. Presentation is one of communication form, as an activity to share a topic, opinion, or information to others, in presentation there were some basic elements: first, a person who do presentation, second was participants or audience, and third the presentation media or device. Learning presentation media was a tool to provide or convey message that helps lecturer in lecture, not replace the overall roles of lecturers but could convey a message effectively and efficiently.

\section{Research methodology}

The presentation in lecture activities using visual aids become an ordinary thing. Current lecture presentation model already using multimedia tools. Many benefits could get by using interactive multimedia learning system which more innovative and interactive, the lecture would combine between the text, pictures and video in one whole of mutual support to the achievement of learning purpose, add learner motivation during the process of learning and teaching until obtained the learning purpose desired.

Lecture presentation model that use cloud based infrastructure was designed through the following stages :

i). First step was preparing the concept of presentation model.

ii). Second, develope the application and the implementation infrastructure.

iii). Third, analyze the implementation result of presentation model based on cloud infrastructure.

For the development of application use the research and development methodology like former research by Ariesto [11] and Budiman [12]. Where this methodology had six steps, it is concept, design, collecting material, assembly, testing, and distribution.

i). Concept - at this stage arranged the development concept to performed, started by literature study from former research and later concluding problems concerned about how to build an learning application based on cloud infrastructure and multimedia learning.

ii). Design - after doing the problem analysis from the concept stage before, then arrange the design of application, infrastructure and the model implementation.

iii). Collecting material - after doing design, the next step is to do the acquisition of lecture material to upload in the application.

iv). Assembly-when design and data acquisitions completed the next step is to do a material compilation that has obtained into the application. And then it was uploaded to a server.

v). Testing - after the application had finished to built, then it tested and reviewed, testing carried out in two stages, namely alpha and beta testing testing. In the alpha phase of testing conducted feasibility validation by media experts and material expert. Validation of the application in terms of learning media performed by three experts media. Validation is done by filling out a questionnaire assessment of applications with a choice of five ratings ranging from very decent to very unfit. 


\section{Result and discussion}

For the implementation and testing were done at Communication Department at Merdeka Madiun University. The application can be used both lecturers and students, and both could create, download, upload or read the lecture material from the application by using internet browser. All the data would save in the cloud so both wouldn't need removable storage media. User in this application divide into two diferent roles, first lecturer role and second was student role, where the differences was the size of storage permission. The storage size for students were smaller than lecturers storage size.

The user of this application could create text document, spreadsheet document, and presentation document straightly trough the application or just upload the those document from the computer. The application also had messenger fiture, where it could be use to chat personaly or create public announcement to all active users. The main page of the application shown in Figure 1.

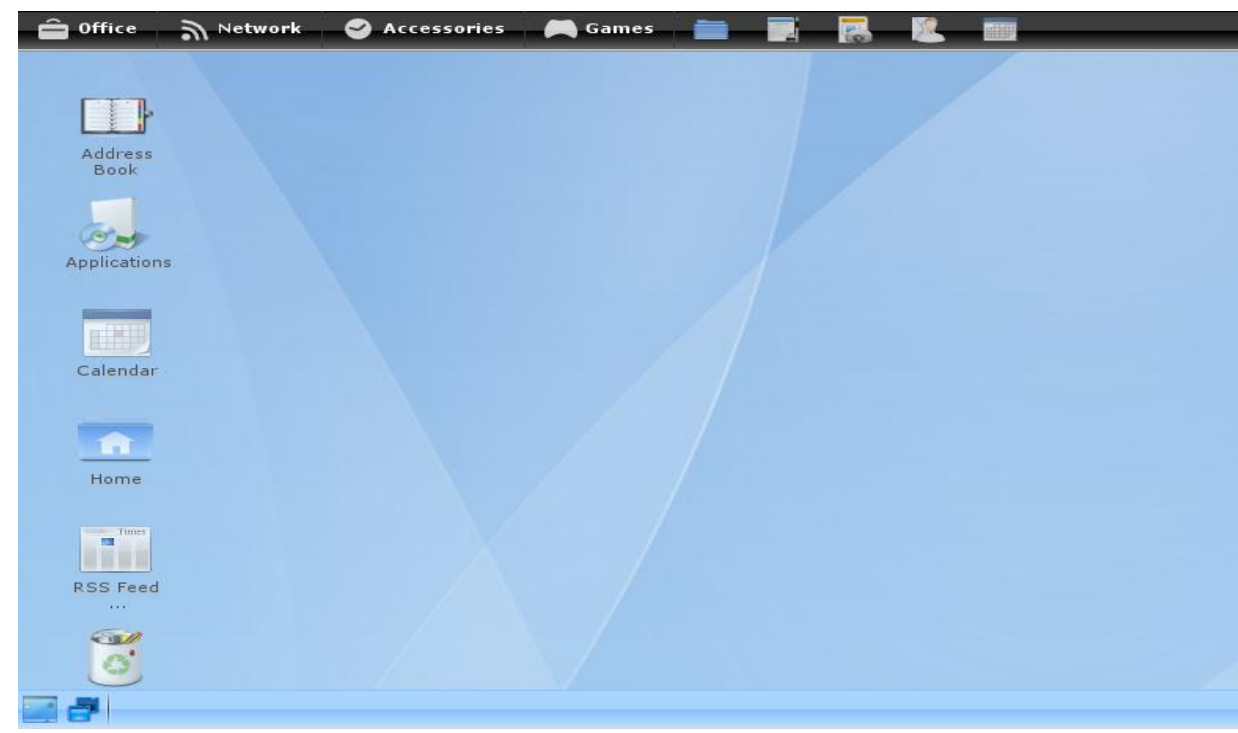

Fig.1. Home interface of the cloud based application.

In the main page shown shortcut to every appilcation provide, like Address Book, Application, Calculator, Home Folder, and RSS Feed. On the top menu shown shortcut to Office Application like Word Processor, Spreadsheet, and Presentation shown in Figure 2 and Figure 3. 


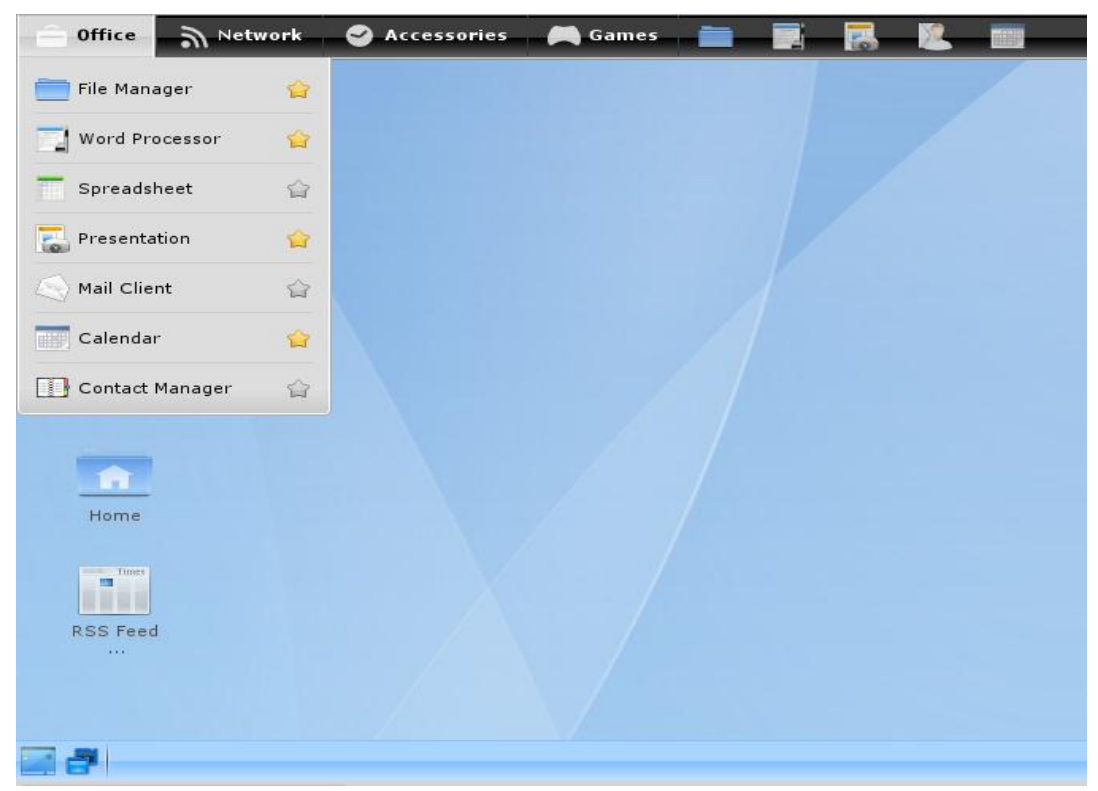

Fig.2. Taskbar menu at cloud based application.

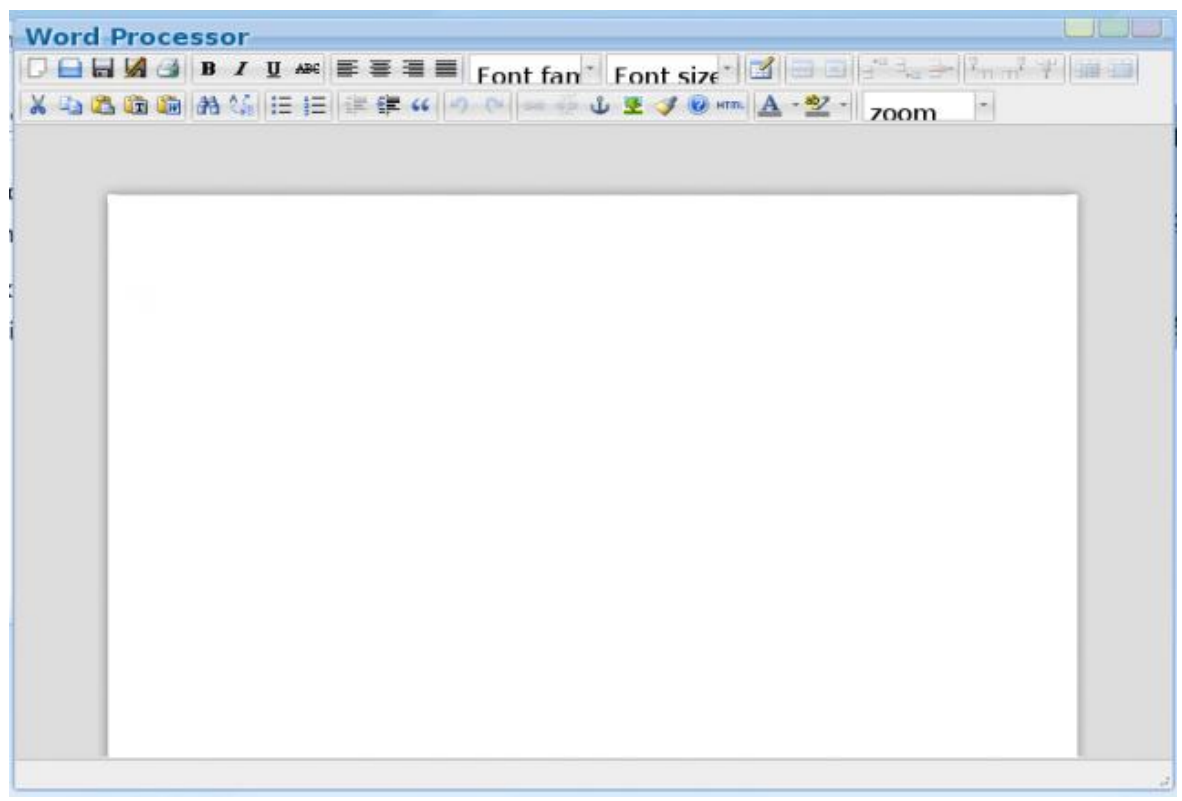

Fig.3. Word processor dan presentation application provide in cloud based application.

For the class implementation, every class would have small form factor computer using Raspberry Pi shown in Figure 4, where it's connected to the network using wireless access to access the lecture material such as word documents or presentation document. And it's also connected to the HDMI port to projector in the classroom. The student could do the same, they could access the lecture material by laptop, smartphone, or tablet through the wireless access like shown in Figure 5. 


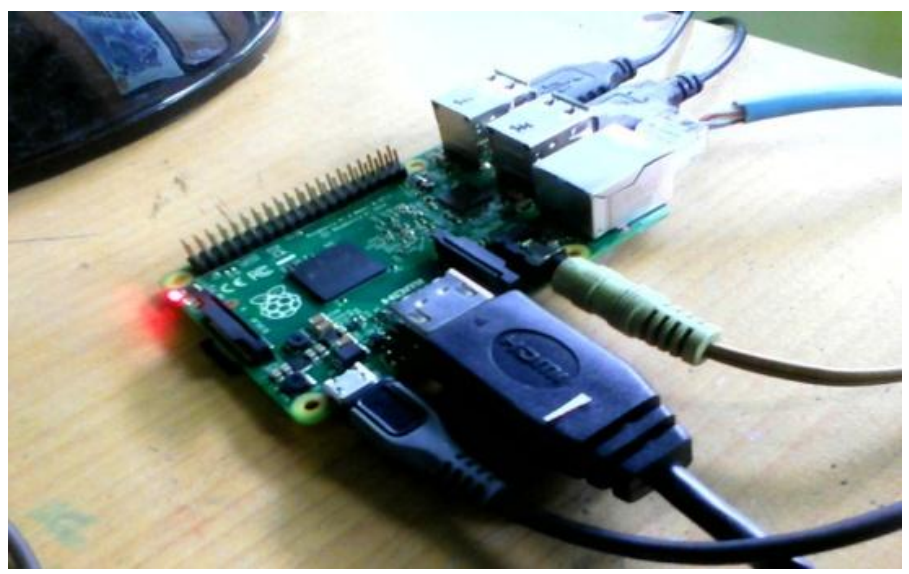

Fig.4. Raspberry Pi2 (small form computer).

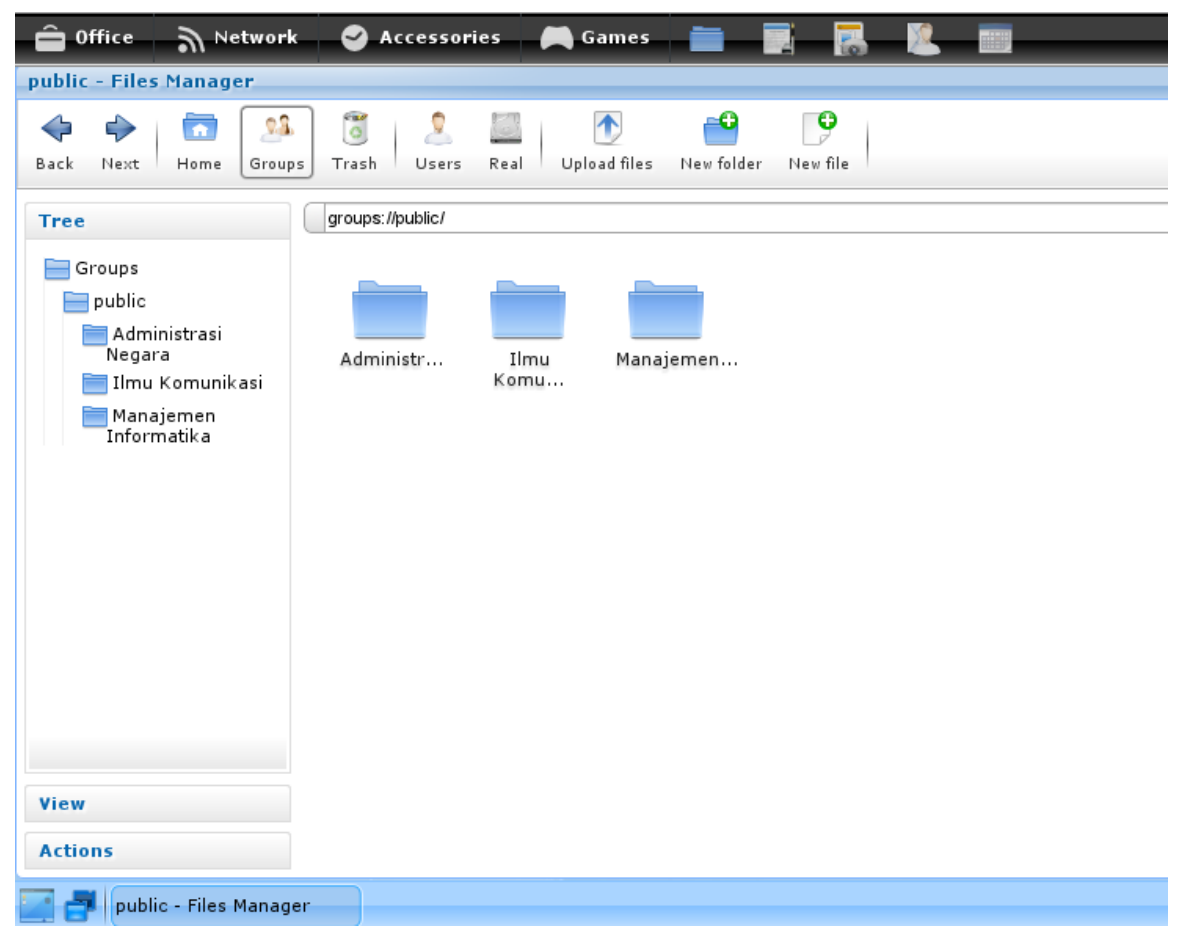

Fig.5. Accessing the lecture material.

After the implementation of the cloud application, then we do the analysis of feasibillity of the application. To measure the result of the cloud based application in this research using quantitative data obtained from feasibility assessment. There are three measurements which are eligibility assessment from media experts. Then for analysis measurement from the result of application developed, this research uses quantitative data obtained from feasibility assessment. There are three measurements which are eligibility assessment from media experts, eligibility assessment for the content material, and eligibility assessment for general public. Quantitative data derived then calculated using the formula adapted from Rizkiansyah [8] research. Then converted into qualitative value by 
comparing a score from the reviewer with an ideal score calculated from conversion table reference as follows:

Table 1. Scoring criteria.

\begin{tabular}{ll}
\hline Score & Category \\
\hline$X>X i+1.80 \mathrm{Sbi}$ & Very Feasible \\
\hline$X i+0,60 \mathrm{Sbi}<x \leq X i+1.80 \mathrm{Sbi}$ & Feasible \\
\hline$X i-0,60 \mathrm{Sbi} i x \leq X i+0.60 \mathrm{Sbi}$ & Quite Feasible \\
\hline$X i-1,80 \mathrm{Sbi} i x \leq X i-0.60 \mathrm{Sbi}$ & Not Feasible \\
\hline$X \leq X i-1.80 \mathrm{Sbi}$ & Very Not Feasible \\
\hline
\end{tabular}

where $(X i)$ was Ideal Average Score which is $1 / 2 \times$ (maximum score + minimum score), ( $S b i)$ was Ideal Deviation Score which is $1 / 6 \mathrm{x}$ (maximum score - minimum score), and $X$ was Average score from implementation. After we have count the quisioner result we have score as follows:

Table 2. Scoring result

\begin{tabular}{llll}
\hline No & Respondent & Score & Category \\
\hline 1 & Media Expert & 71.34 & Feasible \\
\hline 2 & Material Expert & 80.67 & Very Feasible \\
\hline 3 & Students & 84.67 & Very Feasible \\
\hline
\end{tabular}

Cloud based presentation tools application are able to use as a media for creating presentation material or keeping the lecture material both for lecture and students. Testing is done with two stages of testing, namely alpha testing and beta testing. Thus based on the assessment from experts and students, this application fit for use as a new model of presentation media based on cloud infrastructure. In this research also using quisioner to measure user satisfaction, quisioner were sent into three different class, and from the result conclude as follows.

Table 3. Quisioner result.

\begin{tabular}{ll}
\hline Communication Department & Informatics Management Department \\
\hline - The application were little & - The Application were average. \\
difficult to understand. & - Need High Internet Access. \\
- Need high internet access. & - Easy to share article. \\
- The user interface were not & \\
too exiciting. & \\
\hline
\end{tabular}

\section{Conclusion}

The result of this research after the first implementation of presentation model based on Cloud Infrastructure on Communication Department and Informatics Management Department at Merdeka Madiun University were conclude as follows:

i). The application for Presentation Model based on cloud infrastructure were successfully developed and implemented in lecture. Lecture and student both could access the lecture material through internet connection whether in lecture activity (face to face lecture) or outside the lecture activity.

ii). From the feasibility analysis, conclude that the developed application were feasible, so the application could support the presentation model with cloud infrastructure. So 
the Presentaion Model with cloud infrastructure were successfully implemented and could use for further lecture activity.

This work supported by Indonesian Research Technology and Higher Education Department and Merdeka Madiun University Research and Community Service Department.

\section{References}

1. F.P. Suprobo. International Refereed Research Journal, IV(3):79-86 (2013). http://www.researchersworld.com/vol4/issue3/vol4 issue3 1/Paper 08.pdf

2. W. Kim. Journal of object technology, 8(1):65-72 (2009). https://pdfs.semanticscholar.org/6b81/d052c3a4c703e154eb6512c2ccee26076f56.pdf

3. Q. Zhang, L. Cheng, R. Boutaba. Journal of Internet Services and Applications, 1(1):7-18 (2010). https://link.springer.com/article/10.1007/s13174-010-0007-6

4. Zhang, S. Zhang, S. Chen, X. Huo, X. Cloud computing research and development trend. Second International Conference on Future Network, 22-24 January 2010 (Sanya, Hainan, China, 2010). http://ieeexplore.ieee.org/document/5431874/

5. D. Apriono. Prospektus Jurnal Ilmiah Unirow Tuban, 56(2):159-172 (2012). [in Bahasa Indonesia]. http://id.portalgaruda.org/?ref=browse\&mod=viewarticle\&article=105209

6. S. Nasution. Berbagai pendekatan dalam proses belajar dan mengajar. [A variety of approaches in the learning and teaching process]. Jakarta: Bumi Akasara (2000). pp. 7-8. [In Bahasa Indonesia]. http://library.um.ac.id/freecontents/index.php/buku/detail/berbagai-pendekatan-dalam-proses-belajar-mengajar-snasution-38088.html

7. A. Arsyad. Media pembelajaran. [Instructional Media]. Jakarta: Raja Grafindo Persada (2010). pp. 3-4. [in Bahasa Indonesia]. http://library.um.ac.id/freecontents/index.php/buku/detail/media-pembelajaran-azhar-arsyad-24788.html

8. G. Lin, D. Fu, J. Zhu, G. Dasmalchi. IT Professional, 11(2):10-13 (2009). https://www.computer.org/csdl/mags/it/2009/02/mit2009020010.html

9. J. Cappos, I. Beschastnikh, A. Krishnamurthy, T. Anderson. Seattle: A platform for educational cloud computing. SIGCSE Bulletin, 41:111-115 (2009). https://www.cs.ubc.ca/ bestchai/papers/sigcse09.pdf

10. P. Mell, T. Grance. The NIST definition of cloud computing. Gaithersburg: NIST (2011). http://nvlpubs.nist.gov/nistpubs/Legacy/SP/nistspecialpublication800-145.pdf

11. A.H. Sutopo. Multimedia interaktif dengan flash. Yogyakarta: Graha Ilmu (2003). [in Bahasa Indonesia]. http://digilib.unikom.ac.id/repo/sector/buku/view/1/key/9407/MULTIMEDIAinteraktif-dengan-flash.html

12. A. Budiman. D.N. Amadi. International Journal of Advanced Research in Computer Science, 7(3):50-53 (2016).

https://www.researchgate.net/publication/313477014_Development_of_Dhungkrek_D ance Learning_Application to Preserve Local_Culture Existence 